\title{
How to Sustain Mineral Resources: Beneficiation and Mineral Engineering Opportunities
}

\author{
Johan PR De Villiers \\ Department of Materials Science and Metallurgical Engineering \\ University of Pretoria, Pretoria, South Africa
}

\begin{abstract}
The sustainability of a mineral resource depends, among other aspects, on what the mineral in question will be used for, price fluctuations, future resource requirements, and downstream manufacturing. A balance must be struck between the long-term commitment of developing a mineral deposit against the short-term threats of a changing commercial and social environment. Long-term resource sustainability is dependent both on increased efficiency, which improves profitability, and on revitalizing marginal mines. This is illustrated through breakthroughs in the processing of low-grade copper and refractory gold ores, as well as nickel laterite ores. Retreatment of mine wastes and tailings can also increase the sustainability of mining activity. Ongoing research and development is also helping to sustain mineral resource exploitation.
\end{abstract}

Keywords: resource usage, process optimization, recycling, research and development

\section{Introduction}

The sustainability of mineral resources is a subject that is increasingly being discussed at various levels: from local communities associated with mining and mineral processing, to regional and national governments, and at international conferences. These discussions address resource availability, utilization and consequential environmental risks, and the social impacts that accompany the exploitation of commodities. Because of mining's substantial impact on the environment and its generation of large quantities of potentially hazardous waste, it has been, and will be, the subject of intense debate. As a consequence of the increased population and the reduction in poverty, illustrated by "Nearly 1 billion people taken out of extreme poverty in 20 years" (The Economist 2013), there will be an inevitable increase in production of mineral commodities to meet the increased needs for a better quality of life.

In response to the realisation that a secure supply of raw materials is essential for the competitiveness of the European economy, the European Innovation Partnership (EIP) on Raw Materials was established in 2012 and published the Raw Materials Scoreboard in July 2016 (European Commission 2016). This document outlines the future resource requirements of the 
European Union (EU). To strengthen the security of supply, the EU will invest in the diversification of supply, improve conditions for domestic production, and stimulate the recycling of raw materials.

Mining and processing necessarily exploit dwindling resources. Minerals extraction is inherently unsustainable and, eventually, most currently known large high-grade deposits will be developed or depleted. This is most evident in the case of the South African gold industry, which contracted from being, in 1970, the biggest producer of gold, at 1,000 tons (Rockerbie 1999) down to sixth place in 2016 with a production of 140 tons: global gold production in 2016 was 3,100 tons (U.S. Geological Survey 2017). This contraction was due to the fact that many of the large high-grade mines had been depleted and had closed (Limpitlaw 2004). Gold reserves in South Africa are still substantial (Viljoen 2009), but the extreme depths (3,900 $\mathrm{m}$ at the Mponeng Mine) make exploitation expensive and dependent on available energy and water resources.

Minerals extraction is a human activity that is highly visible, extremely invasive, and often damages the environment. Open cast mining, together with mine waste disposal, can sterilise large tracts of land, which in many cases can be impossible to reclaim. Acid mine drainage often results from sulfide ore mining and is difficult to control, and, in many countries, remediation is often neglected. Unfortunately, most public perceptions of the mining industry are negative and reinforced by media coverage of major catastrophic events, such as coal mine disasters, tailings dam collapses, cyanide leakage in rivers, and acid mine water spills. None of these were more dramatically and publicly portrayed in the media than the successful rescue of 33 trapped Chilean miners at the San Jose Mine near Copiapó during the summer/autumn of 2010. This emphasized the inherent dangers associated with mining. Conversely, downstream industry has managed to convey a positive image of environmental awareness, with examples of the reduction of fossil fuel use by electricity generation using wind or photovoltaic sources.

That there will be increased use of raw mineral commodities is inevitable. To address the issues surrounding this situation, this article will evaluate the sustainability of the minerals industry; discuss future resource requirements and the factors influencing resource development and sustainability and the recycling of commodities; examine sustainability with respect to the efficient and novel processes for the extraction of mineral commodities; and discuss some commodities and waste materials that are currently under-exploited and that research could make more accessible. 


\section{Resource requirements in future}

A condensed and graphic history of raw materials extraction is given in the Raw Materials Scoreboard (European Commission 2016). This highlights the dramatic 40 -fold increase in the use of construction materials from 1900 to 2009, as compared to ores and industrial minerals which saw a 31-fold growth over the same period. During the period 1950-2010, raw material consumption levelled off for most countries, except for some countries in Asia where the increase in consumption has been exponential, rising approximately 14 -fold in this period (Fig. 1).

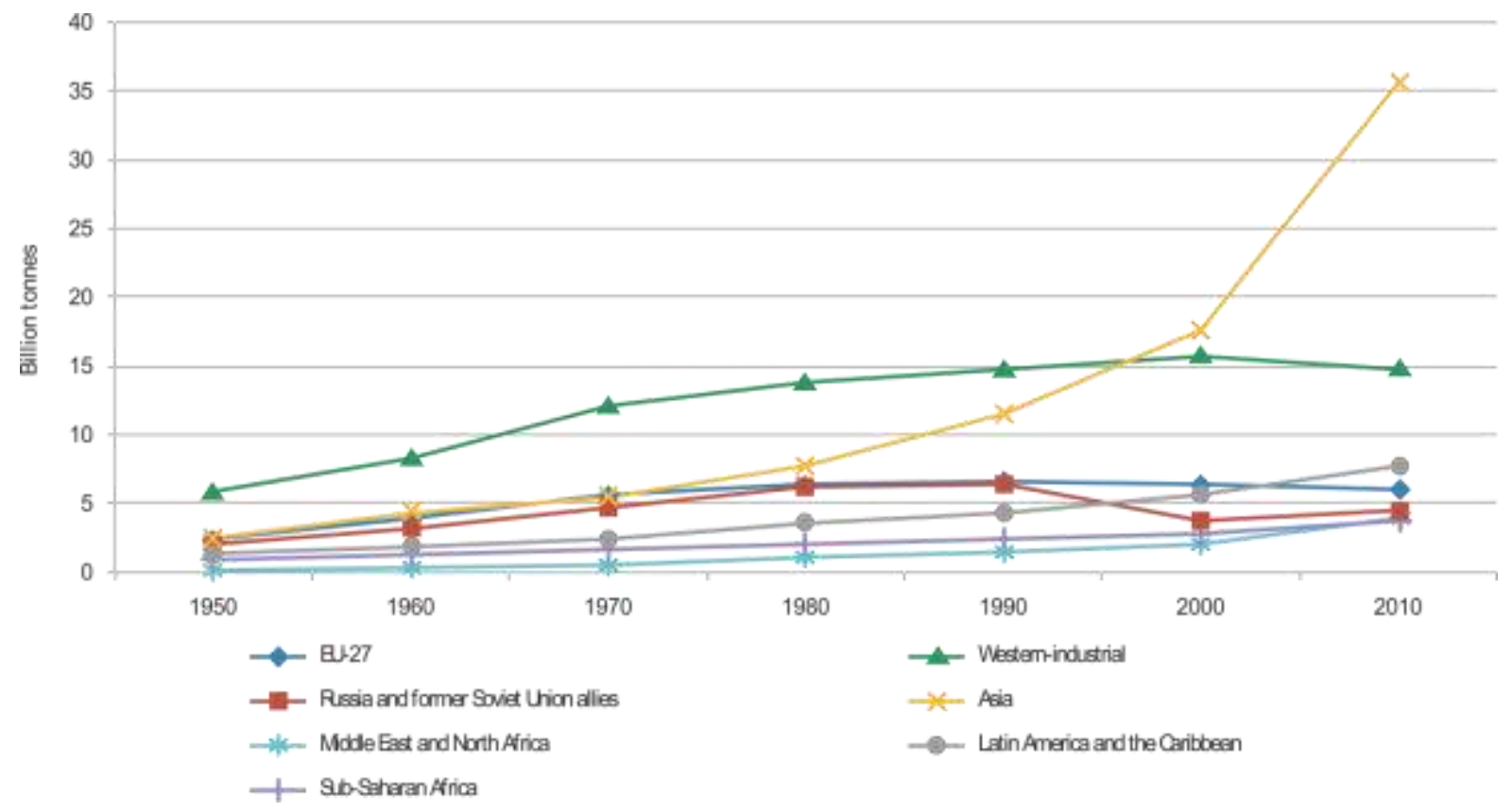

Figure 1. Global material extraction by resource type (1950-2010). Reproduced with permission from European Commission (2016)..

This means that the Asian region will dominate consumption during the next few decades, with resource use expected to double between 2010 and 2030. However, the largest increases in global mineral resource production in the near future will be for elements needed for the low-carbon technologies (e.g. wind power, solar-photovoltaic cells, electricity generation), and biofuel technologies. Some of the elements needed for all these technologies include dysprosium, chromium, cobalt, gallium, indium, neodymium and silicon.

\section{Features of resource development and exploitation}

There are three factors that currently limit the development and exploitation of resources: (1) global pricing of the raw ore, (2) time, and (3) cost of environmental compliance. 
The global price of ore can dictate the success or failure of a mining company. The economic importance of global prices on the mining industry, as compared to a downstream industry (those that convert an ore into derivative products) is graphically illustrated in Figure 2A. On this diagram, it can be seen that the raw ore is the predominant source of revenue (86\%) for the mining company. In contrast, for downstream companies, the cost of the ore can be a mere fraction $(<1 \%-20 \%)$ of the overall production costs. This dramatically shows that the cost of ore for downstream industries can be truly insignificant, and the price of the ore does not strongly impact on their profitability. On the other hand, the price of the ore has a huge direct impact on the source mine's profitability and sustainability. This was dramatically shown during the recent sharp drop in iron-ore prices (Fig. 2B). The price of iron ore dropped from $\$ 154$ per ton in February 2013 to $\$ 41$ per ton in December 2015, causing many mining companies to shut down or drastically curtail production. Furthermore, this price drop significantly and negatively impacted the national economies of the major producing companies operating in Australia and Brazil.

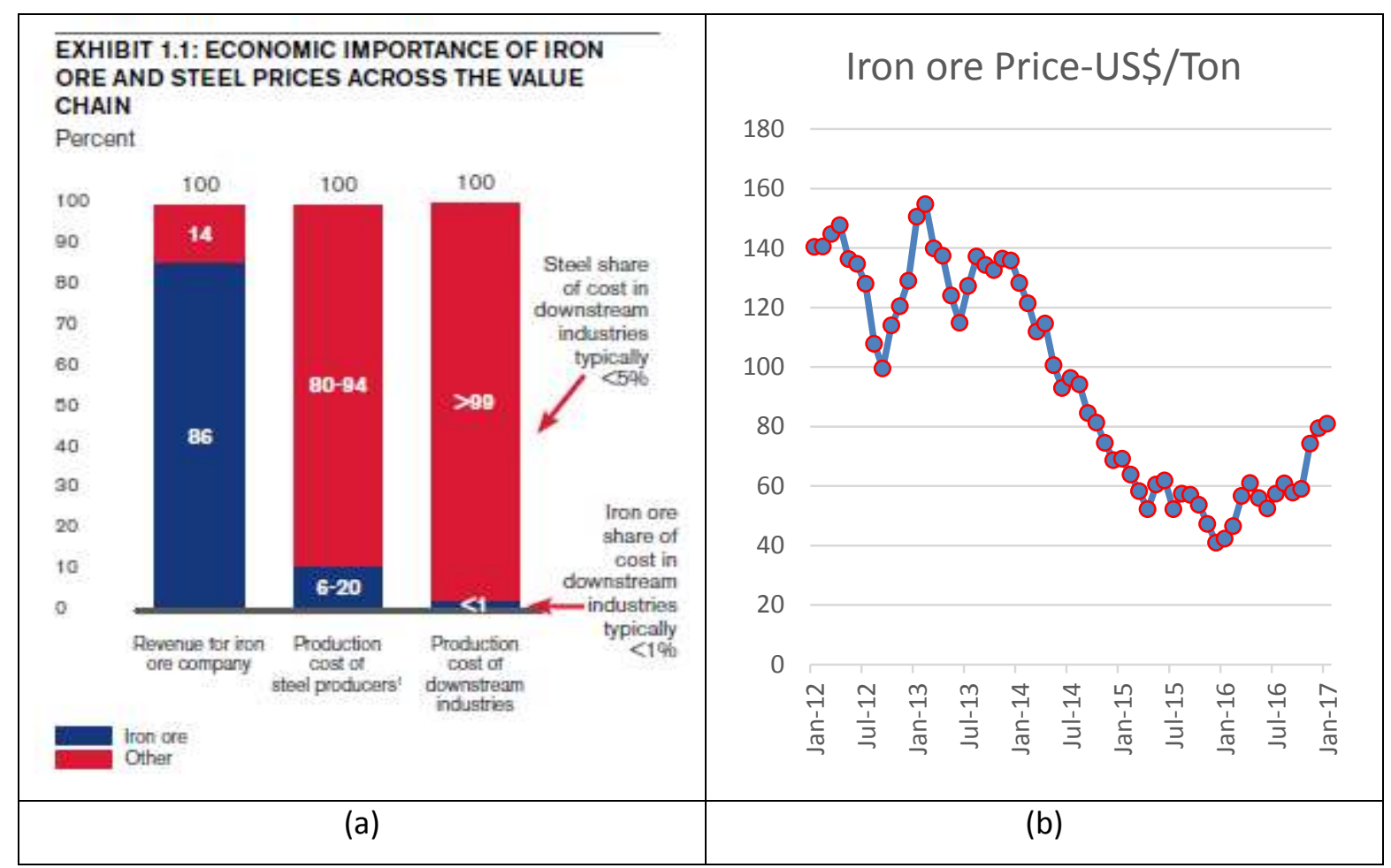

Figure 2. A) The economic importance of iron ore and steel prices as relevant to the primary ore producer (e.g. mining company) and the downstream cost of that iron (as a percentage of total costs) to a steel producer and to other downstream industrial users of iron. Steel and iron ore share of cost in downstream industries is typically lower than $5 \%$ and 1\%, respectively. Used with permission from Anglo American (2011). (B) Iron-ore price fluctuations over the period April 2012 to March 2017. Data from Indexmundi (2017). 
Time is another major factor in resource development. The development of a major new mineral resource can take 10 years or more. There needs to be a large commitment by a company to a resource's eventual implementation, but with that are the concomitant risks of a changing commercial environment, funding challenges, and societal responsibilities. An example is the development of the world-class Voisey's Bay Nickel deposit (Canada), which was discovered in 1993. It was auctioned off in 1996, but mining only started in 2005 (Gibson 2006). Mine development also carries short-term risks, such as commodity price volatility as exemplified by the oil price collapse of 2015-2016, which took place over 6 months, and the iron-ore price decline over 12 months. In addition, production disturbances, such as strikes and work stoppages due to unforeseen technical problems, can further disrupt production. Thirdly, legislative actions, such as licensing changes, can delay production for months, as happened earlier in 2017 at the Grasberg copper (and gold) mine in Indonesia. Resource rental taxes and local beneficiation (increasing mine product quality) demands can further impact on the profitability of resource development. All these short-term risks can have negative impacts on the long-term developmental sustainability of a mining project.

One other important factor affecting the sustainability of a mining operation is the cost of environmental and social responsibilities associated with the operation moving increasingly towards sustainable development. Because the profitability of the mining industry is poor - an average rate of return is only $5 \%$ (Humphreys 2001) - estimated environmental costs that amount to an additional $3 \%$ of operating costs can be difficult to sustain. In some countries, environmental costs can amount to $23 \%$ of development costs. These costs can, however, be offset by increased productivity and increased efficiency of extraction by adopting low-cost technologies, such as bioleaching and solvent extraction.

\section{Recycling}

Increased recycling is seen as an essential component of the 'circular economy', where commodities are used and re-used on a continuous basis. Recycling has been practiced in the steel and aluminium industries for many years, and the logistics for recycling are well in place. In a recent study of the extent of recycling of selected major-element commodities (UNEP 2011), a number of metals showed high recycling rates, whilst others are recycled to a lesser extent. Table 1 summarises the extent of metal recycling. In the case of ferrous metals and steel, as well as for the precious metals, the recycling rates are quite high. But recycling rates drop to less than $1 \%$ for many metals such as the rare earths, vanadium and zirconium. It is clear that for the major metallic commodities, recycling can ensure the continued availability of major resources. However, this carries a 
commitment to select, collect and accumulate specific commodities so that they can be re-used. This function is not necessarily carried out by either the primary producer or the user and is difficult where the commodities are present in small or trace amounts or are widely distributed among various products.

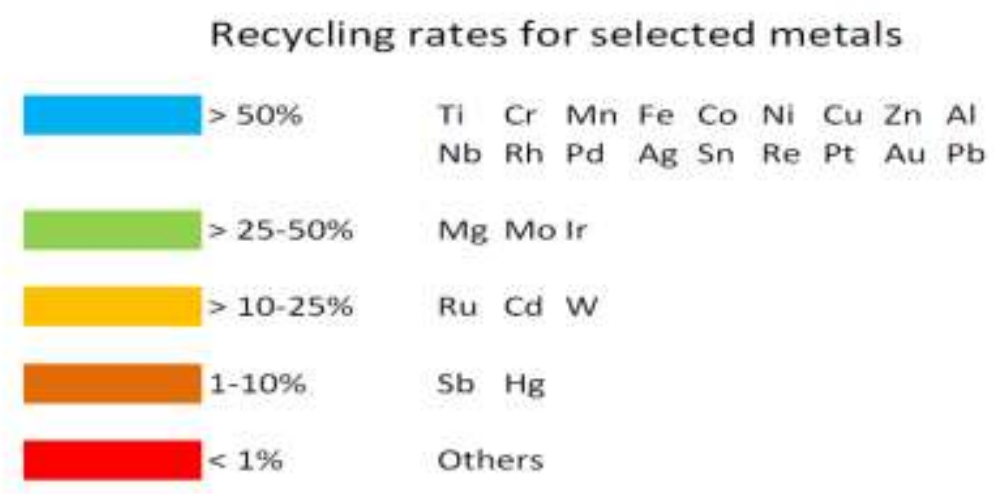

Table 1. Recycling rates for selected metals. Base metals and precious metals have a recycling rate of over $50 \%$, but among the 'Others' category would be the rare-earth elements. DATA FROM UNEP (2011)

\section{Process optimization}

Optimization of extraction processes can enhance the profitability of mining activities, thereby extending the life of mining and metallurgical operations. For example, worldwide platinum-group element production in 2013 was 12.9 billion ounces, which was valued at US\$14.4 billion (JohnsonMatthey 2013). Recovery of the metals from the primary ore mined varies from $75 \%$ to $85 \%$ and ongoing efforts are made to increase this figure. A $1 \%$ increase in recovery translates to an increase in revenue of $\$ 140$ million per year, usually at little extra cost. At the platinum-group metals Lonmin mine in South Africa it was stated that, "underground and overall concentrator recoveries increased to $85.1 \%$ and $85.0 \%$ from $80.5 \%$ and $79.0 \%$ respectively year on year" (Lonmin 2010 ). This translates to an increase in revenue of $\$ 64$ million for the company. From the same company, key features of platinum-group processing are given and shown in Table 2. The biggest cost factor is mining itself (at $65 \%-70 \%$ of total costs), with milling and flotation coming in second (at $9 \%-12 \%$ of total costs). On the other hand, the biggest potential increase in revenue could come from the milling/flotation step where recovery is only $80 \%-90 \%$. Compare these figures to the very efficient process steps involving in smelting/converting and in base-metals refining and precious metals refining, all of which have efficiencies of 95\%-99.8\%. Increases in efficiency in mining and milling/flotation will, therefore, contribute most to increases in profitability and sustainability. Mineralogical methods, such as liberation analysis, have also contributed significantly to increasing the recovery of valuable 
elements (Cabri 2010). Additionally, by-products such as copper, nickel and gold, as well as minor elements such as selenium and tellurium, can also add to the profitability of platinum-group mining.

\begin{tabular}{|c|c|c|c|c|c|c|}
\hline Parameter & Mining & $\begin{array}{l}\text { Milling } \\
\& \\
\text { Flotation }\end{array}$ & $\begin{array}{c}\text { Smelting } \\
\& \\
\text { Converting }\end{array}$ & $\begin{array}{l}\text { Base Metal } \\
\text { Refining }\end{array}$ & $\begin{array}{l}\text { Precious } \\
\text { Metal } \\
\text { Refining }\end{array}$ & Total \\
\hline $\begin{array}{c}\text { Percent of Total } \\
\text { Cost }\end{array}$ & & $9-12$ & 6 & 7 & $4-5$ & 100 \\
\hline PGE Grade & $4-6 \mathrm{~g} /$ ton & $\begin{array}{c}100-600 \\
g / t o n\end{array}$ & $\begin{array}{l}640-6000 \\
\text { g/ton }\end{array}$ & $30-65 \%$ & $>99.8 \%$ & - \\
\hline $\begin{array}{c}\text { PGE Recovery } \\
(\%)\end{array}$ & - & & $95-98$ & $>99$ & $98-99$ & $75-85$ \\
\hline $\begin{array}{c}\text { Concentration } \\
\text { Ratio }\end{array}$ & - & $30-80$ & 20 & 75 & 2 & 200000 \\
\hline $\begin{array}{l}\text { Processing } \\
\text { Time (days) }\end{array}$ & - & 2 & 7 & 14 & $30-150$ & Up to 170 \\
\hline
\end{tabular}

Table 2. Key features of PGE extraction. The numbers in the orange highlighted boxes are the most crucial in terms of cost and profitability. REPRODUCED FROM LONMIN (2010).

Increased efficiency in copper-ore processing is exemplified by the application of the two-stage hydrometallugical process of solvent extraction/electrowinning, together with heap leaching, both methods having effected huge improvements on the profitability and sustainability of many mines and transformed the copper industry (Bartos 2002). This has been especially the case in the treatment of low-grade, otherwise uneconomic, ores and mine discards, as well as in revitalising abandoned mines.

The application of bio-hydrometallurgy involving bacterial leaching is hailed as the next revolutionary breakthrough in both gold and copper recovery processes (Bartos 2002; Clark et al. 2006). In the case of gold processing, this involves the leaching of gold-containing sulfide minerals, such as arsenopyrite and pyrite, to liberate the occluded gold, which is then leached with cyanide. In copper processing, the leaching of chalcopyrite, which is poorly soluble in dilute sulfuric acid, can be greatly improved by bioleaching. This will make the solvent extraction/electrowinning treatment of chalcopyrite-containing ores a viable and sustainable process. This technology has been implemented at a number of mines up to a scale of 1 million tons per annum (Clark et al. 2006). Again, advanced mineralogical methods are important to identify and quantify the various readily and poorly soluble copper minerals, as well as the location of gold in the pyrite, arsenopyrite or 
both. Where and in what form the gold actually is would influence the choice of processing methods to be used.

Iron-ore sintering is a technology that has been in operation for decades, but its use is now increasing in importance. The increasing use of soft goethitic ores and fine-grained upgraded ores has led to the need for agglomeration in order to use these ores in blast furnaces (Cores et al. 2010). Sintering is the preferred method to achieve a suitable blast furnace feedstock and, as such, is extensively used worldwide. Again, this technology ensures the utilization of ores that were previously deemed unsuitable. Additional benefits include better feedstock quality, more suitable blast furnace operation and better steel quality, all because sinters are now the preferred feed for blast furnaces worldwide. Figure 3 illustrates the sintering process by showing the combustion bed in the background and the moving sinter bed in the foreground.

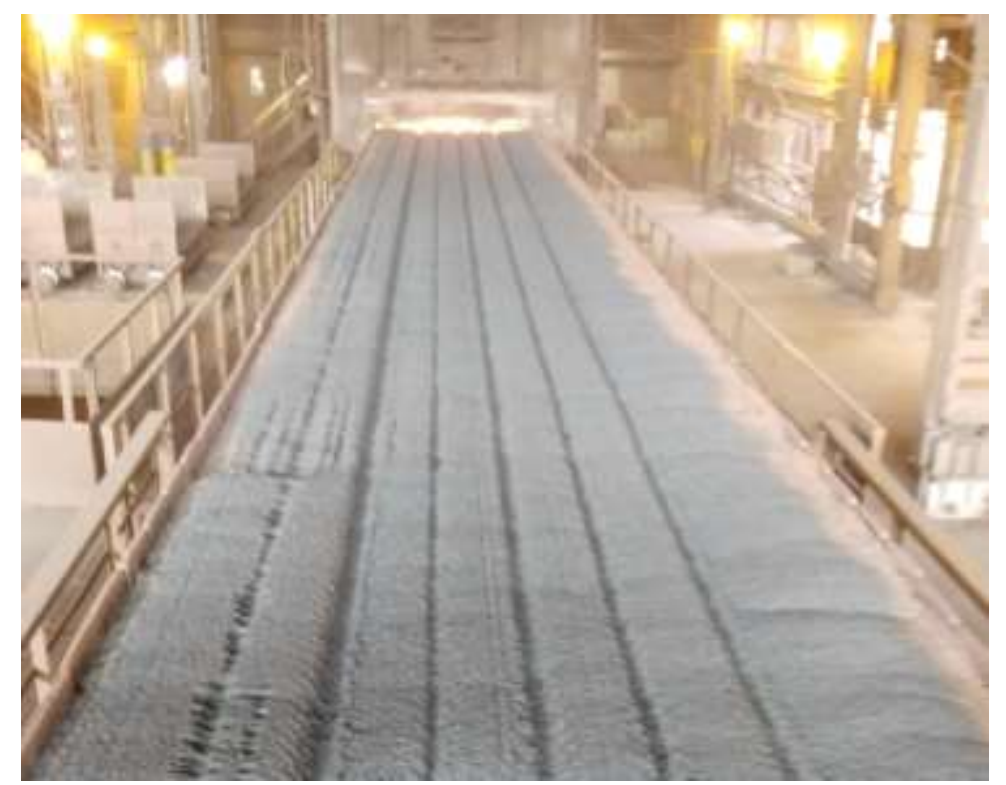

Figure 3. Sinter bed where the flame at the top of the bed moves downward by suction from below and ignites the fine-grained agglomerated ore resulting in a hard strong sinter.

\section{Opportunities for mineral resource research and development}

As part of the wider sustainability goals, the lifetime of major mineral deposits needs to be extended. There are still a few easily accessible mineral deposits for which mineral extraction is quite straightforward. However, there are also a wide range of (often) very large deposits that are not so easily exploited and for which little attention has been given. The section below details different methods by which certain types of mineral resources, including those already associated with previous mining activities, can be better exploited. 


\subsection{Iron-ore mining waste utilization}

At many iron-ore mines (Fig. 4), the ores are usually beneficiated to a grade of $62 \% \mathrm{Fe}$ or $65 \% \mathrm{Fe}$. As a result, large amounts of ore that do not meet these specifications (e.g. that in the range of $50 \%-60 \%$ Fe or below) are discarded. This discarded material can be potentially upgraded to a higher quality, more valuable, commodity that can have a grade of $+60 \% \mathrm{Fe}$. Extensive research is ongoing into upgrading such waste iron ore. At present, this is done by pulsed gravity separation (jigging) instead of heavy media separation (Naudé et al. 2013). Clearly, the life of the mine can be extended without incurring large additional mining expenses. The fine particles generated by comminution of the ore can also be beneficiated, usually by flotation followed by pelletisation, to make the product suitable for blast furnaces.

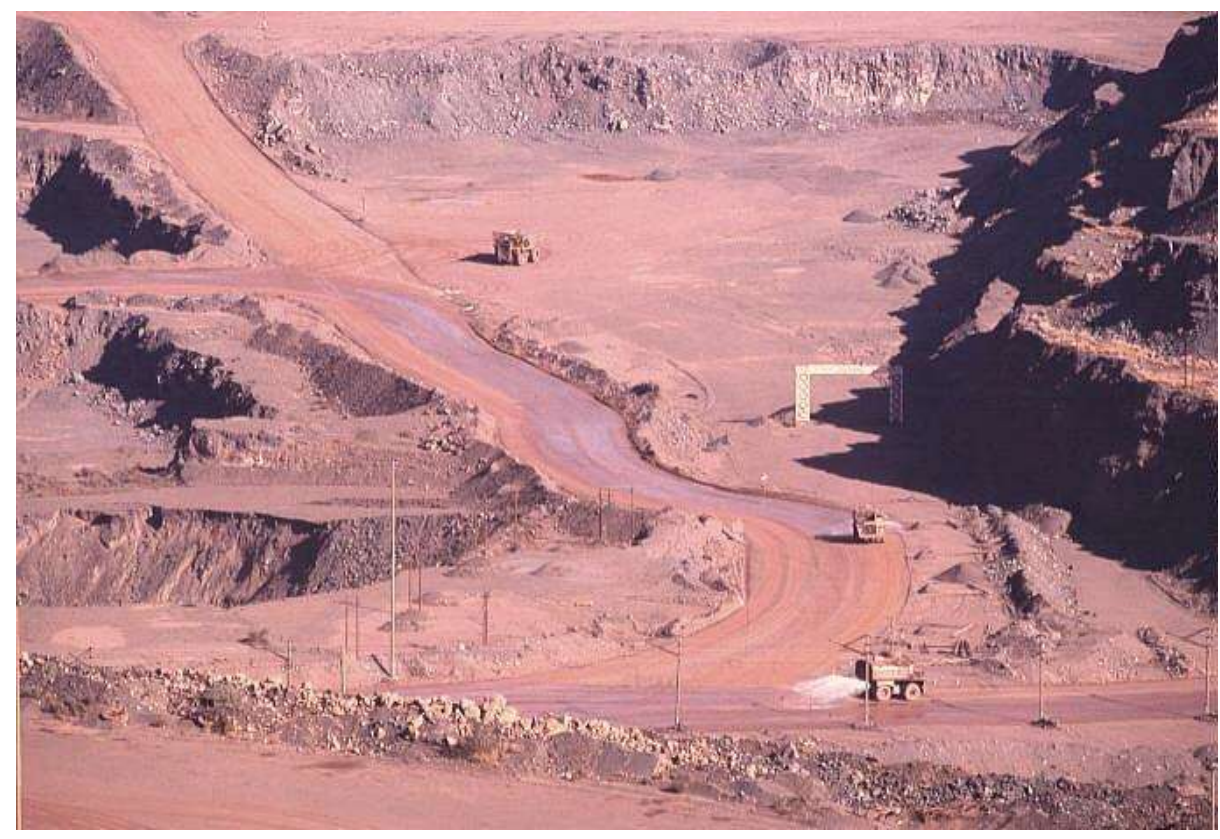

Figure 4. A section of the Sishen iron ore mine (South Africa), part of Anglo American's Kumba Iron project. Photo courtesy of Natasia Naudé, University of Pretoria

\subsection{Waste processing}

To decrease the environmental impact of concrete production and reduce associated $\mathrm{CO}_{2}$ emissions ground granulated blast-furnace slag, which is a glassy by-product of pig iron and steel manufacturing, is commonly used to produce blast-furnace slag cements and slag-concrete mixtures (Flower and Sanjayan 2007). Another potentially important recycling process is the recovery of titanium and residual vanadium from waste steelmaking slag produced from titaniferous magnetite. This slag contains appreciable amounts of titanium compounds that could be upgraded by flotation, gravity separation or chemical treatment by acid leaching. Figure 5 shows coarse-grained reduced $\mathrm{M}_{3} \mathrm{O}_{5}$ (where $\mathrm{M}=$ metal) with a pyroxene and perovskite. 


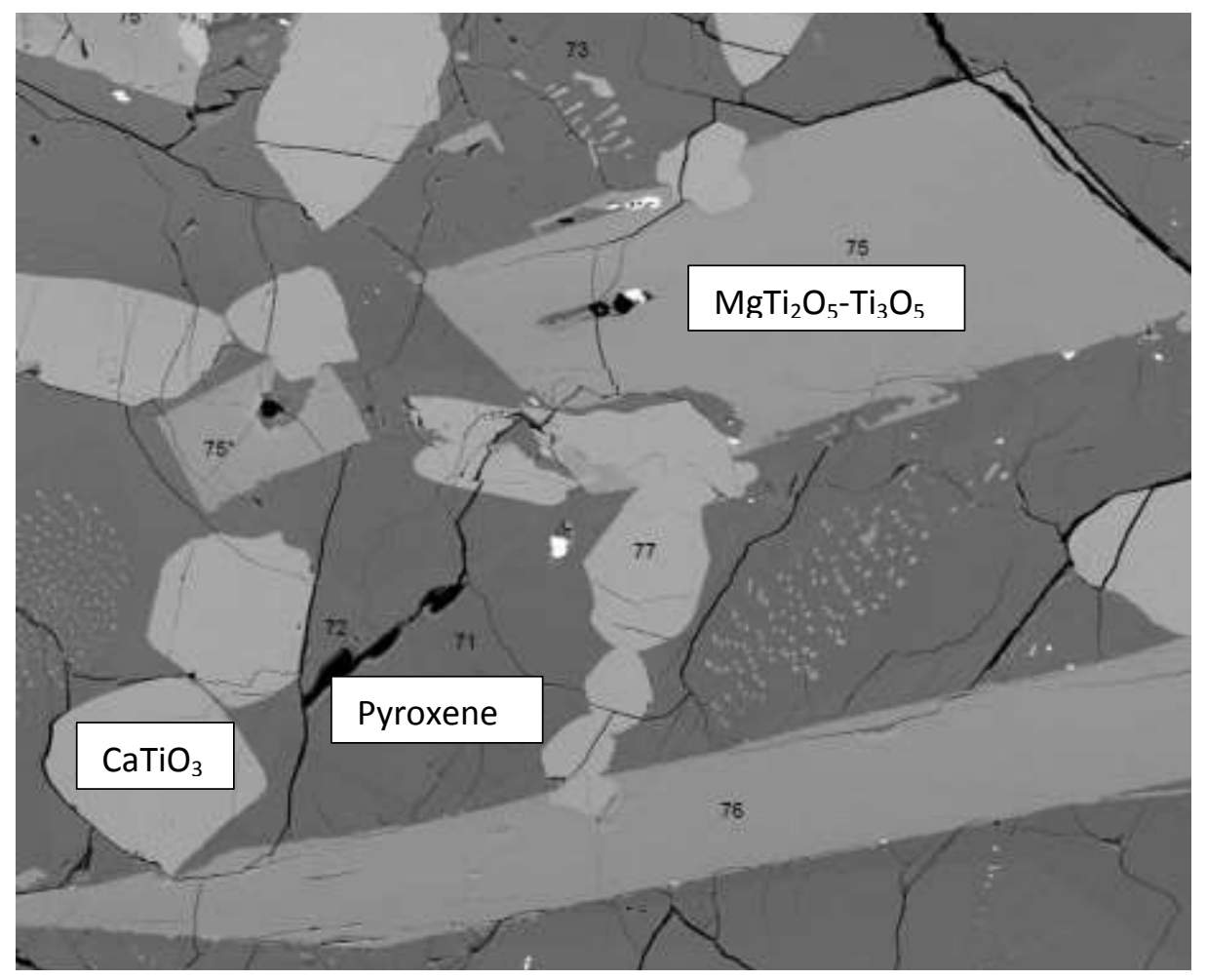

Figure 5. Backscattered electron image of a titanium-containing slag from Evraz-Highveld Steel and Vanadium Limited. Numbers (mostly in the 70s) are analysis positions. Phases present include ferro-pseudobrookite, perovskite, pyroxene and some exsolution phenomena. Courtesy of Johan Nell of Hatch Ltd.

\subsection{Tailings re-processing}

Reprocessing gold-containing tailings dumps has been practised for many years in South Africa, and extensive dumps are still available. This practice recovers gold that is usually associated with sulfide minerals and that is not easily accessible through direct cyanidation. The cost of processing is normally very low because the tailings are already mined, comminuted and lying on the surface. All that is required is excavation, gentle milling or attritioning followed by flotation to recover a goldbearing concentrate that can contain 1.3-1.9 g/ton Au (Fleming et al. 2010). Tailings as low as 0.3 $\mathrm{g} /$ ton Au can be economically recovered. Again, the viability of gold mining can be extended by reprocessing (Viljoen 2009).

Recently, reprocessing tailings that contain platinum-group elements (PGEs) has also commenced (notably in South Africa). These tailings arise from the upgrading of chromite ores, all of which contain PGEs to a variable extent (Naldrett et al. 2009). The products are PGE concentrates that are toll-smelted and a chromite concentrate that is sold to ferrochrome producers. Additionally, large tonnages of tailings from the processing of the platiniferous Upper Group 2 (UG-2) chromite ore 
from South Africa are also being investigated for re-treatment and recovery of residual PGEs and iron-rich chromite.

\subsection{Titanium production}

Titanium is a lightweight metal, is the fourth most abundant metal element after $\mathrm{Al}, \mathrm{Fe}$ and $\mathrm{Mg}$, and is used for applications that demand high strength-to-weight ratios, especially in the aerospace industry. It is still produced using the Kroll and Hunter processes, which are batch processes. Both processes are based on the metallothermic reduction of $\mathrm{TiO}_{2}$ by magnesium or sodium, respectively, and are costly and time-consuming (Zhang et al. 2011). These processes are followed by re-melting and purification of the titanium sponge to remove magnesium (or sodium) and oxygen, again in batch processes. This makes titanium 40 times more costly than steel and 20 times more costly than aluminium, with little likelihood of cost reduction. Can these costs come down?

Table 3 gives a comparison between the global production of these metals. Ti, Mg, AI AND STAINLESS STEEL IN 2014. DATA FROM USGS (2015) AND ISSF (2016).

\begin{tabular}{|l|l|}
\hline Metal & $\begin{array}{l}\text { Production (Million Tons) in } \\
2014[21],[22]\end{array}$ \\
\hline Titanium sponge & 0.192 \\
\hline Magnesium & 0.910 \\
\hline Aluminium & 58.3 \\
\hline Stainless Steel & 41.7 \\
\hline
\end{tabular}

Table 3 gives a comparison between the global production of these metals. It is clear that the high cost of titanium prevents its widespread use. A viable lower-cost alternative for the Kroll and Hunter processes has yet to be developed, the US Department of Energy having already investigated 17 different "emerging reduction technologies" (Kraft 2004). The FFC Cambridge process - an electrochemical process developed during 1996/1997 by Tom Farthing, Derek Fray and George Chen at the University of Cambridge (UK) - was hailed as a highly promising, potentially low cost, new method of producing titanium metal, but no large-scale facility has been forthcoming despite millions of dollars of investment. Metal powder technology company Metalysis (based in the UK) built a small industrial facility to demonstrate tantalum and titanium production in 2014, but whether any larger-scale facilities will appear in the future remains to be seen.

Major research and development opportunities exist for the development of a major underexploited resource with a market estimated to be worth $\sim \$ 10$ billion per annum. 


\subsection{Processing of titaniferous magnetite}

This resource is largely untapped because of its poor suitability as feedstock for blast furnaces: the main smelting route is by using electric arc furnaces. The blast furnace method is used for smelting titaniferous magnetite mainly in China and Russia. It is estimated that some 20 million tons of crude steel is produced from this resource (total world steel production in 2015 was 1,622 million tons). This amounts to approximately $1.2 \%$ of total output. Valuable by-products include vanadium and a potential titania slag, both of which could contribute to an increased cash flow.

So, this major resource of more than $\sim 50$ billion tons (Fischer 2015 ) is vastly under-utilised, and research and development is needed to make it more amenable to blast furnace operation. Electric arc furnace smelting is expensive and cannot compete with blast furnaces unless cheap hydroelectric power is available. The titanium-rich electric arc furnace slag that currently contains the fluxes used in the production of pig iron is discarded, despite containing $>30 \% \mathrm{TiO}_{2}$. Some efforts have been made to recover the titanium oxide and the residual vanadium either by hydrometallurgical treatment or by nitridation.

\subsection{Lateritic nickel technologies}

Laterite nickel constitutes approximately $60 \%$ of known nickel resources, and because of the low nickel content $(1 \%-2 \% \mathrm{Ni})$ its processing presents a number of challenges. Firstly, the ore does not lend itself to upgrading because of the low-grade distribution of nickel among different, often dispersed, very fine-grained phases (Butt and Cluzel 2013). Consequently, in the pyrometallurgical production of ferronickel, the high slag-to-metal ratio (40 to 50) due to the low nickel content and the high magnesium content results in a high power consumption during the processing procedure.

High-pressure acid leaching has been attempted in a number of localities, with limited success: a number of plants that attempted the process were forced to close. The low nickel content is also a big cost factor and an impediment to profitability. In addition, costly titanium pressure vessels have to be used and the disposal of the leach residues remains a challenge. Recently, Chinese technology has been developed for the low-cost production of nickel pig iron using blast furnace technology. This pig iron product can then be used for the production of alloys and stainless steel (von Krüger et al. 2010).

Significant opportunities exist, then, for upgrading low-grade nickel ores. If the grade can be increased from $1 \%$ to $2 \%$ by upgrading, the slag-to-metal ratio can be halved with a huge 
saving in electricity cost and slag disposal cost. In addition, metal production can effectively be doubled with the same throughput. Mineralogical input to assist upgrading technologies such as flotation will be crucial in this regard.

A better understanding of the mineralogy, together with improved processing technologies can affect the process economics of Ni-laterites. This is the case of the Ni-laterites of Eastern Australia, which contain rare earths and scandium (Chassé et al. 2017). The development of appropriate hydrometallurgical technologies yields high purity oxides (a purity better than $99 \% \mathrm{Sc}_{2} \mathrm{O}_{3}$ ) as the final products. This would not be possible with other processing techniques and could result in the exploitation of a new generation of deposits developed in laterites and exploited for commodities such as $\mathrm{Ni}$ and rare metals. The selective extraction of these critical metals has been the key to considering these deposits as candidates for development.

\section{Factors affecting future resource sustainability}

Sustainability of mineral resources is dependent on a number of factors (listed below) that can affect the viability and development of future mining activities and investment in this sector.

- The time it takes to develop a new mine. The development of a new mining operation carries a long-term commitment that can take as long as 10 years. Short-term factors, such as commodity price fluctuations, changes in the regulatory environment and social perceptions can seriously undermine this commitment, to the detriment of the industry.

- The maturity of national economies. The future sustainability of mineral resources is considered to be adequate as a result of increased recycling and levelling off of demand as economies become more mature.

- The rise in reprocessing mineral processing waste and tailings. Reprocessing existing waste can extend the production of a commodity, whilst also reducing heavy-metal pollution and acid mine drainage.

- The need to recycle rare metals. Such recyling will increase substantially as the use of rare metals expands, provided an adequate means of scrap collection can be developed.

- The development of novel cost-effective technologies. These will prove essential to process low-grade orebodies and the waste materials derived from mining operations.

- The increasing need to develop lower-grade open cast orebodies. Such orebodies will inevitably be brought onstream, but their development will also impact significantly on the environment.

- The rise in opportunities for researchers to better process unexploited and low-grade ores.

\section{References}

Anglo American (2011) The South African Iron and Steel Value Chain. Kumba Iron Ore. Anglo American. Available at: http://www.adcommission.gov.au/cases/EPR\%20251\%20\%20300/EPR\%20300\%20\%20archived\%2013\%20December\%202016/055\%20-NON-CONFIDENTIAL\%20ATTACHMENT\%20D\%20\%20South\%20Africa.pdf. 17 pp 
Bartos PJ (2002) SX-EW copper and the technology cycle. Resources Policy 28: 85-94

Butt CRM, Cluzel D (2013) Nickel laterite ore deposits: weathered serpentinites. Elements 9: 123-128

Cabri LJ (2010) Process mineralogy in the Pt industry and future trends. Proceedings of the 11th International Platinum Symposium, June 21-24, 2010. Ontario Geological Survey, Sudbury, Canada, Miscellaneous Release Data-269

Chassé M, Griffin WL, O’Reilly SY, Calas G (2017) Scandium speciation in a world-class lateritic deposit. Geochemical Perspectives Letters 3: 105-114

Clark ME, Batty JD, van Buuren CB, Dew DW, Eamon, MA (2006) Biotechnology in minerals processing: technological breakthroughs creating value. Hydrometallurgy 83: 3-9

Cores A, Babich A, Muñiz M, Ferreira S, Mochon J (2010) The influence of different iron ores mixtures composition on the quality of sinter. ISIJ International 50: 1089-1098

European Commission (2016) Raw Materials Scoreboard. The European Innovation Partnership on Raw Materials. European Commission, 108 pp

Fischer RP (1975) Vanadium Resources in Titaniferous Magnetite Deposits. US Geological Survey Professional Paper 926-B. US Government Printing Office, Washington, pp B1-B10

Fleming CA, Brown JA, Botha M (2010) An economic and environmental case for re-processing gold tailings in South Africa. In: 42nd Annual Meeting of the Canadian Mineral Processors, Ottawa, Ontario, Canada, 19-21 January 2010. Reprinted in SGS Minerals Technical Paper 2010-03

Flower DJM, Sanjayan JG (2007) Greenhouse gas emissions due to concrete manufacture. International Journal of Life Cycle Assessment 12: 282-288

Gibson RB (2006) Sustainability assessment and conflict resolution: reaching agreement to proceed with the Voisey's Bay nickel mine. Journal of Cleaner Production 14: 334-348

Humphreys D (2001) Sustainable development: can the mining industry afford it? Resources Policy 27: 1-7

Indexmundi (2017) [Iron-ore price fluctuations.]

http://www.indexmundi.com/commodities/?commodity=iron-ore

ISSF (2016) Stainless Steel in Figures 2016. International Stainless Steel Forum, https://aceroplatea.es/docs/StainlessSteelFigures2016.pdf 26 pp

Johnson-Matthey (2013) Platinum 2013. Johnson-Matthey, London. Available at: http://www.platinum.matthey.com/documents/market-review/2013-interim/full-review/english.pdf 40 pp

Kraft EH (2004) Summary of Emerging Titanium Cost Reduction Technologies. A Study Performed for US Department of Energy and Oak Ridge National Laboratory, subcontract 4000023694, December 2003. EHK Technologies Vancouver. $55 \mathrm{pp}$

Limpitlaw D (2004) Mine closure as a framework for sustainable development. Sustainable Development Practices on Mine Sites - Tools and Techniques, University of the Witwatersrand, pp 1-10

Lonmin (2010) Lonmin Plc Third Quarter 2010 Production Report and Interim Management Statement. Lonmin Plc, 6 pp 
Naldrett AJ and 6 coauthors (2009) Chromite composition and PGE content of Bushveld chromitites: Part 1 the Lower and Middle Groups. Applied Earth Science 118: 131-161

Naudé N, Lorenzen L, Kolesnikov AV, Aldrich C, Auret L (2013) Observations on the separation of iron ore in a prototype batch jig. International Journal of Mineral Processing 120: 43-47

Rockerbie DW (1999) Gold prices and gold production: evidence for South Africa. Resources Policy 25: 69-76

The Economist (2013) Towards the end of poverty. 1 June 2013

https://www.economist.com/news/leaders/21578665-nearly-1-billion-people-have-been-taken-out-extremepoverty-20-years-world-should-aim

U.S. Geological Survey (2017) Mineral Commodity Summaries 2017. U.S. Geological Survey, doi.org/10.3133/70180197, $202 \mathrm{pp}$

UNEP (2011) Recycling Rates of Metals - A Status Report. A Report of the Working Group on the Global Metal Flows to the International Resource Panel. United Nations Environment Programme. See www.unep.org/resourcepanel/United Nations Environment Program. 48 pp

USGS (2015) United States Geological Survey Mineral Commodity Summaries 2015. https://doi.org/10.3133/70140094, 196 pp

Viljoen M (2009) The life, death and revival of the central rand Goldfield. World Gold Conference 2009. The Southern African Institute of Mining and Metallurgy, pp 131-138

von Krüger P, Silva CA, Vieira CB, Araújo FGS, Seshadri V (2010) Relevant aspects related to production of ironnickel alloys (pig iron containing nickel) in mini blast furnaces. Proceedings of the Twelfth International Ferroalloys Conference (Infacon XII), Helsinki, Finland, 6-9 June 2010, pp 671-680

Zhang W, Zhu Z, Cheng CY (2011) A literature review of titanium metallurgical processes. Hydrometallurgy 108 : 177-188 